\title{
Slaughter of Ethics: A Glimpse into the Horrors of Meat Industry in Ruth Ozeki's My Year of Meats
}

\author{
Adhavapriya S. and G. Ruby Davaseeli \\ Department of English, Kanchi Mamunivar Government Institute \\ for Postgraduate Studies and Research, Puducherry, India
}

\begin{abstract}
It's an indisputable fact that meat production and consumption have global consequences. Animal agriculture functions to guarantee maximum profit. To carry out the operation seamlessly, the system must resort to ruthlessly efficient practices. The purpose of this research is to analyze the ethical implications of such practices. The greed of the corporate agencies and the question of animal welfare are openly addressed in the novel My Year of Meats by Ruth Ozeki. Animals in factory farms undergo horrible treatment and are exploited in every way with no regard to their personal autonomy. To satisfy consumers' desire for meat and economically benefit in the process, sentient animals are being exploited. This paper takes in various aspects, from the commercialization of meat to the use of synthetic hormones like DES, the questionable practices in the feedlot, and the inhumane process of slaughter, of the meat farming industry as depicted by Ozeki and examines whether it is morally and ethically correct.
\end{abstract}

\section{KEY WORDS: MY YEAR OF MEATS, COMMERCIALIZATION OF MEAT, DES, FEEDLOTS, SLAUGHTERHOUSE}

\section{INTRODUCTION}

Animal farming in the United States has a history that is tied inextricably to the maximization of profit. James McWilliams in his chapter titled "The Origins of Factory Farming in the United States" questions how, setting aside profit being the goal, the system of mass production of meat that slaughters 10 billion animals a year came to be in the first place (117). According to him, this phenomenon was caused as humans slowly distanced themselves from animals due to urbanization. The reason factory farming boomed was due to the "general indifference to the welfare of the animals under their care and an exclusive emphasis on mechanised efficiency" (McWilliams 118).

As the gap between human-animal relations widens, commercial marketing and advertising tools are profusely used to justify the consumption of meat. The victims in this scenario are the sentient non-human animals that have their sentience disregarded. In his chapter

Biosc Biotech Res Comm P-ISSN: 0974-6455 E-ISSN: 2321-4007

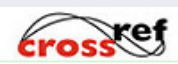

Identifiers and Pagination

Year: 2021 Vol: 14 No (8) Special Issue

Pages: 69-72

This is an open access article under Creative

Commons License Attribn 4.0 Intl (CC-BY).

DOI: $h t t p: / / d x$.doi.org/10.21786/bbrc/14.8.17
"Animal Self-Awareness: Types, Distribution, and Ethical Significance" David DeGrazia establishes that a lot of animals have bodily agential self-awareness with aims and goals, and that "members of highly social species exhibit social self-awareness" (79).

My Year of Meats (1998), the debut novel of AmericanCanadian author Ruth Ozeki, details the lives of two women, Jane Takagi-Little and Akiko Ueno. Jane lives in the United States and Akiko in Japan. In the exposition of the story, both Jane and Akiko are at low points in their lives. Jane is jobless with no other source of income, eating vegetarian food, and freezing in her cold apartment because her rent is overdue. The narrative, historically, is such that a vegetarian diet indicates poverty while a diet that includes meat indicates power and success. Carol J. Adams in her groundbreaking work The Sexual Politics of Meat states how "According to the mythology of patriarchal culture, meat promotes strength" (56). This is best exemplified when Akiko's husband Joichi Ueno, who "believed in meat" (Ozeki 27), forces her to eat it in the hopes that it would make her put on weight and restart her menstrual cycle.

He constantly compares himself to the quintessential white American male and wishes his wife shared his beliefs as well. His obsession with the American culture is so intense that he orders Akiko to address him thus: "Joichi is not a modern name. From now on, call me
Article Information

Received: $14^{\text {th }}$ Apr 2021

ccepted after revision: $14^{\text {th }}$ June 2021 
'John”' (27). Working for an advertising agency in Japan, his job is to bring US meats into the Japanese household through a TV series called My American Wife! In Japan, Joichi gives Akiko the job of watching the show and providing feedback on each episode through a rating system. He also makes her cook the dishes as specified by the participants of the show, and taste test them. The American coordinator for the production team is Jane. The goal of the show is to display the wholesomeness of meats produced in America. Jane, roped into the world of factory farming through her role as a coordinator in the show, cannot give up her passion for documenting, and it makes its way into this new job, and through it, she ends up uncovering disturbing truths about the industry. The key turning point of the novel happens when Jane discovers that she has been a victim of this industrial greed, and thus sets out to expose the truth at a great personal cost.

Synthetic Hormones and the food Industry: Any food that is modified genetically will have gone against the course of nature. Molly Wallace opposes GM foods by saying they cause discomfort, and that genetically modified inventions that seem wondrous today will end up being disasters of tomorrow, such as global warming, mad cow disease, CFCs, and BPA used in plastics (Wallace 156). In My Year of Meats, Jane interviews Helen Dawes and Mr. Purcell for an episode of My American Wife! Accompanied by Joichi Ueno, she goes to the Dawes house and asks Helen questions about her cooking to get her to open up and gather more information for her script. When asked what she cooks for the family, it is Mr. Purcell who reveals that they eat chitterlings, hog maws, and chicken. The Dawes have nine children, so they cannot afford anything but pigs' large intestines to make chitterlings and stomach to make hog maw. They like chicken, but since the prices have gone up they instead find parts of chicken at the meatpacking house that are cheap but taste good.

Though affordable, the reason they stop consuming the cheap variant is due to it causing bodily changes in Mr. Purcell. Helen describes the change in his voice as, "Yeah, we thought they was real good... until Mr. Purcell's barrytone came out soudin' serpraner!" (Ozeki 139), to which Mr. Purcell explains "It was some medicine they was usin' in the chickens that got into the necks that we was eatin'... An' that medicine, well, if it didn't start to make me sound just like a woman!" (139). She also adds that it altered his appearance, for he began to grow breasts. With the increase in the cost of meat, those who desire to consume but cannot afford it turn to cheap alternatives that become a health hazard as is the case with the Dawes; "his socio-economic conditions influence him in a negative way" (BALCI 1318). When Joichi Ueno, who is partial to beef, asks Mr. Purcell why he doesn't like steak, Mr. Purcell replies “Red meat's too costly with so many mouths to feed" (Ozeki 139). Steven McMullen views the system of animal agriculture from a capitalist lens and says how genetic deformities are the norm.
Though the animals subjected to the modifications grow quicker and bigger, "Productivity is not, in other words, a good metric for well-being" (McMullen 127). Jane senses this truth and with her curiosity as a documentarian pushing her to investigate further into the issue, she does. When she discovers the use of the synthesized estrogen DES, or diethylstilbestrol in meat production, she is changed forever. She finds that DES castrates the male chickens instantly. Though it's cost-effective, the side effect is that "The males develop female characteristicsplump breasts and succulent meats-desirable assets for one's dinner" (Ozeki 148). From there, she learns how the FDA banned DES in the poultry industry but didn't stop the beef industry from using them. Using the hormone reduces the time it normally takes a cow to reach the required weight for slaughter by one month and cuts down about five hundred pounds of feed. Almost all of the U.S. livestock used DES by then. Farmers that inhaled or ingested it developed issues such as "impotence, infertility, gynecomastia (enlarged and tender breasts), and changes in their voice register" (Ozeki 149). It wasn't necessary for cattle to graze in the open anymore, as confining them in factory farms and using DES was enough to fatten them up quicker.

Parallel to its use in animal agriculture, DES was also being prescribed to pregnant women. Though it was later discredited, doctors and pharmaceuticals, believing it prevented miscarriage and premature births, advertised it to expecting mothers. It was decades later that scientists linked its use on mothers to a type of cancer called clear cell adenocarcinoma. Male babies born of DES developed "descended and atrophied testicles, abnormally undersize penises, defective sperm production, and low sperm count, all of which increased the risk of testicular cancer and infertility" (Ozeki 150). After many struggles, DES was finally banned in cattle feed. Still, when it was found that some farmers implanted DES illegally on cows, they weren't punished by the law. Jane concludes her research by stating that synthetic hormones are still used in 95\% of feedlots. "In 1989, Europe banned the import of U.S. meat because of the use of hormones in production" (151), and her TV show's sponsor BEEF-EX turned to Japan for business and thus My American Wife! was born.

Questionable Practices in the Feedlots: Another family that Jane chooses to interview is the Dunns. Mrs. "Bunny" Dunn and her much older husband John are from Texas, where they own a feedlot. It's a big operation, with about 20,000 cattle coming in from all over the country. If it were a ranch, then numbers may have been less than half of that. In her fax to Ueno, Jane mentions how the Dunns feed special food to the cows to increase their weight and get them immune to sickness. From a production perspective, she implores how convenient it would be to capture the view if all the animals were congregated in a single space like with the Dunns feedlot. The family has also given the team permission to film footage of the whole meat production process. Unbeknown to her, Jane's compulsion to expose the truth bubbles out and she looks forward to capturing the horrors inside the 
slaughterhouse. But she soon realizes that doing so will jeopardize her career and confesses all her discoveries to Ueno, hoping he will understand the severity of the situation. He instead advises her not to interfere and just do what is expected of her. He ultimately threatens to fire her if she doesn't stay out of it.

With her course set out for her, Jane goes to visit the Dunns feedlot. It is run by Bunny's husband John and Gale, his elder son from a previous marriage. John also has a little girl with Bunny named Rose. The feedlot is set miles apart from the Dunns' house to provide sufficient privacy and guarantee a smooth operation. The structure of the patch is severe, with animals grouped according to their breed, looking "antithetical to the randomness of living things" (Ozeki 300). Despite the industrial arrangement, the stench of the animals cannot be masked. The ammonia and other gases emanating from the excretion and urine of the cows diffuse the air around. Gale introduces himself as the one in charge. He supervises the mixing of medicine into the feed. When asked what medicine he uses, he lists out a few growth supplements and hormones. It is while talking about what he feeds the animals that Jane is horrified. Gale, to cut cost and time, recycles the feed among the cattle. He calls it their "exotic feed program" (304) and it entails him using recycled newspapers and cardboard, "by-products from potato chips, breweries, liquor distilleries, sawdust, wood chips.

We even got by-products from the slaughterhouserecycling cattle right back into cattle. Instant protein" (304). Jane's camera operator Dave calls this practice illegal, but Gale simply reassures them that it's America and since it's done locally, there can't be any issues. Without any remorse, he also excitedly reveals that they use plastic hay to make the delivery process easy, "you only need a tenth of a pound compared to four pounds of hay. That's a forty-to-one ratio" (305). When a cow is slaughtered, they cut open its stomach and make new pellets out of the undigested pounds of plastic stored there. On top of that, the U.S. Department of Agriculture run tests that feed the cows cement dust to increase their calcium intake, for they "put on weight thirty percent faster than normal feed, and the meat was more tender and juicy" (305). Since the feed they use for the cows is expensive, "and the cattle shit out about twothirds before they even digest it" (306), they recycle the excretions to save even more money. Pregnant cows eat a lot, but they don't easily put on weight since all the energy goes to keeping the fetus alive.

To counter it they feed the pregnant cows a hormone called Lutalyse, which instantaneously aborts the fetus. The feedlots are profit-oriented and to achieve that, the farmers behind these enterprises cannot be emotionally invested. Gale is unbothered by any of the choices he makes because his concerns do not lie with the welfare of the animals that suffer inside his feedlots nor with the people consuming the animals, but towards increasing his profit margin. In his critique of the book Zoopolis, Tine Stein states how the fundamental differences between humans and animals do not justify their unethical treatment (Stein 58). But that is exactly how people like Gale justify their practices.

The kill floor: The slaughterhouse of the Dunns is a rectangular building with a sewer pipe sticking out on the side that expels blood and offal into a truck. Before getting in, the cameras that Jane's team uses to film have to be covered to avoid getting drenched in blood from all the slaughtering. The inside of the slaughterhouse is described as hell, with all the senses being overpowered. With various machines constantly being in motion at a breakneck pace, the noise is incessant. Everywhere they see, parts of cows are moving around on conveyor belts. Bodies of meat hanging by the hind legs from the ceiling move at great speed. With all the slaughter, there is blood in various shades of red everywhere, "bright red, brick red, shades of brown and black; flowing, splattering, encrusting the walls, the men" (Ozeki 330). Even with the strategically placed drains, there is blood and flies throughout the place. The body is sorted by different organs and stored. In a cart, Jane sees yellow liquid coming from pieces of livers, a result of the use of hormones.

The killing floor is dubbed as the "hot floor" "because blood is hot when it pours from a living body! (331). Workers stand on raised ground to cut the meat part by part. "Evisceration is done with a quick slice up the belly, releasing the entails, which pour out in a cloud of steam" (331). Seeing the other cows getting killed, the cow next in line exhibits fear by hesitating to enter the knocking pen. But it's pushed inside using an electric prod. Once settled, with its mouth frothing and eyes rolling back, a worker stuns the cow by injecting a bolt into its brain. Even though Jane sees that the worker did not completely stun the cow, she cannot do anything to stop the next step which is hanging it in the air by its hind legs. With the cow screaming in fear, its throat is finally sliced open. And the unexpected blood that rushes out of the cut makes a crew member slip and fall on Jane, who gets hit by the meat and blacks out.

\section{CONCLUSION}

In the essay "Animals and the Question of Literature," Isobel Karremann answers the question of the social function of literature by looking at how it deals with "the emerging field of cultural animal studies" (Karremann 21). The livestock industry functions indirectly proportional to the welfare of animals, and it is the animal-protection movement that criticizes the sector most (Wilkie 6). When Jane first takes the job of coordinating My American Wife! she has no idea how it is going to change her life. She does not belong to any animal-protection movement, yet she rightly criticizes the industry as she journeys across each American household. Being exposed to DES as a fetus, Jane herself is a victim who ultimately loses her child to miscarriage after her accident at the slaughterhouse. She shows how animals are viewed as nothing more than commodities and how that view does more harm than good. "All sentient animals have 
an interest in liberty because they can suffer from the interference of other agents in their lives" (Giroux 37) and that suffering is explicitly showcased by Ozeki in My Year of Meats.

\section{REFERENCS}

Adams, Carol. (2010) The Sexual Politics of Meat (20th Anniversary Edition). Bloomsbury Academic.

Adem, BALCI. (2017) "When Species Me(a)t: Overlapping Stories of the Victimized Animals and Women in Ruth L. Ozeki's My Year of Meats.” Ankara Üniversitesi Dil ve Tarih-Co囚rafya Fakültesi Dergisi - DTCF Dergisi, vol. 57, no. 2, pp. 1311-22. Crossref, doi:10.1501/ dtcfder_0000001563.

DeGrazia, David. (2019) "Animal Self-Awareness: Types, Distribution, and Ethical Significance." The Routledge Handbook of Animal Ethics, edited by Bob Fischer, Routledge, p. 79.

Giroux, Valéry. (2016 ) "Animals Do Have an Interest in Liberty." Journal of Animal Ethics, vol. 6, no. 1, pp. 20-43. JSTOR, www.jstor.org/stable/10.5406/ janimalethics.6.1.0020. Accessed 18 Apr. 2021.

Karremann, Isobel.( 2013) "Animals and the Question of Literature." Social Alternatives, vol. 32, no. 4, , pp. 21-27. ProQuest, https://search-proquest-com. library.britishcouncil.org.in:4443/scholarly-journals/ animals-question-literature/docview/1508688119/se- 2?accountid=145163.

McMullen, Steven. (2015) "Is Capitalism to Blame? Animal Lives in the Marketplace.” Journal of Animal Ethics, vol. 5, no. 2, pp. 126-134. JSTOR, www.jstor. org/stable/10.5406/janimalethics.5.2.0126. Accessed 18 Apr. 2021.

McWilliams, James. (2019) "The Origins of Factory Farming in the United States: An Overview." The Routledge Handbook of Animal Ethics, edited by Bob Fischer, Routledge, pp. 117-118.

Ozeki, Ruth. (2013) My Year of Meats. Canongate Books.

Stein, Tine. (2015) "Human Rights and Animal Rights: Differences Matter." Historical Social Research / Historische Sozialforschung, vol. 40, no. 4 (154), pp. 55-62. JSTOR, www.jstor.org/stable/24583245. Accessed 18 Apr. 2021.

Wallace, Molly. (2011) "Discomfort Food: Analogy, Biotechnology, and Risk in Ruth Ozeki's All Over Creation.” The Arizona Quarterly, vol. 67, no. 4, pp. 155-181,183. ProQuest, https://search-proquest-com. library.britishcouncil.org.in:4443/scholarly-journals/ discomfort-food-analogy-biotechnology-risk-ruth/ docview/1510997065/se-2?accountid=145163.

Wilkie, Rhoda.( 2017) “Animals as Sentient Commodities." The Oxford Handbook of Animal Studies, edited by Linda Kalof, Oxford University Press, pp. 279-301. 